\title{
Some factors influencing the intestinal digestibility of ruminal undegraded nitrogen estimated with the mobile nylon bag procedure
}

\author{
Y Beckers, A Théwis, B Maudoux
}

Faculté des Sciences Agronomiques, passage des Déportés 2, 5030 Gembloux, Belgium

The methodological factors studied in this experiment were the incubation time in the rumen, the site of recovery and the pore size of nylon bags. Meat and bone meal (MBM), soybean meal (SBM) and wheat bran (WB) were incubated in the rumen of 3 steers (Beckers et al, 1993). Approximately $0.8 \mathrm{~g}$ undegraded feed milled through a $1-\mathrm{mm}$ screen was placed in each bag $(2.5 \times 4.5 \mathrm{~cm})$. Twelve bags per treatment were inserted at a rate of 1 bag every 15 min ( 6 by feeding time) into the duodenum (T-cannula) of 4 sheep. Half the bags were recovered at the ileum (T-cannula) and half in the faeces of each sheep. They were subsequently machine washed $(3 \times 5 \mathrm{~min})$, then dried at $60^{\circ} \mathrm{C}$ for $48 \mathrm{~h}$ and weighed. Intestinal digestibility of undegraded $N(\mathrm{DgN})$ was determined as the proportion of Kjeldhal- $\mathrm{N}$ lost from the bag during the passage through the intestine. DgN of the unincubated feed $(0 \mathrm{~h})$ was also determined.

As expected $\mathrm{DgN}$ decreased significantly with increasing incubation time in the rumen (table I). However, the effect of the feed was important (significant interaction). The decline of $\mathrm{DgN}$ appeared to reach an asymptotic line for MBM. For WB, DgN was unaffected up to $4 \mathrm{~h}$ of incubation but beyond decreased as for MBM. In the case of SBM, DgN decreased significantly between 0 and $8 \mathrm{~h}$ of incubation and then surprisingly increased. As a con- sequence, differences between feeds depended on incubation time.

The site of recovery of the bag had a low but significant effect on the results (table I). This effect was only influenced by incubation time for WB. $\mathrm{DgN}$ measured at the ileum were higher than that determined in the faeces for WB incubated 4, 8, 16 and $24 \mathrm{~h}$. This fact is probably due to the bacterial contamination of bags in the large intestine (Varvikko and Vanhatalo, 1990). DgN obtained with $42.5 \mu \mathrm{m}$ pore-size bags were clearly greater than when measured with $10 \mu \mathrm{m}$ bags. This relationship was unaffected by the feed, the ruminal incubation time, or the site of recovery of bags.

The results emphasize that rumen incubation is an important prerequisite for intestinal digestibility of feed $N$ in the ruminant particularly the real ruminal transit time of feed. This procedure needs to be standardized and calibrated with in vivo digestibilities determined, for example, by the infusion method.

This study was supported by IRSIA (Brussels). Beckers $Y$, Théwis $A$, Maudoux $B$, François $E$ (1993) Ann Zootech 42, 126

Varvikko T, Vanhatalo A (1990) Br J Nutr 63, $221-229$

Table I. $\mathrm{DgN}(\%)$ of the feed in the intestine in relation to incubation time in the rumen, pore size and recovery site of the bags.

\begin{tabular}{|c|c|c|c|c|c|c|c|}
\hline & \multicolumn{5}{|c|}{ Ruminal incubation time (h) } & \multirow[b]{2}{*}{24} & \multirow[t]{2}{*}{ Mean } \\
\hline & 0 & 2 & 4 & 8 & 16 & & \\
\hline $\begin{array}{l}\text { Feed } \\
\text { MBM } \\
\text { WB } \\
\text { SBM }\end{array}$ & $\begin{array}{l}82.7 \\
81.7 \\
95.6\end{array}$ & $\begin{array}{l}68.5 \\
81.8 \\
88.1\end{array}$ & $\begin{array}{l}67.2 \\
81.6 \\
87.3\end{array}$ & $\begin{array}{l}63.2 \\
77.0 \\
85.7\end{array}$ & $\begin{array}{l}61.8 \\
60.8 \\
92.6\end{array}$ & $\begin{array}{l}57.3 \\
59.2 \\
\text { ND }\end{array}$ & $\begin{array}{l}66.7^{a} \\
73.5^{b} \\
89.8^{c}\end{array}$ \\
\hline $\begin{array}{l}\text { Site of recd } \\
\text { lleum } \\
\text { Faeces }\end{array}$ & $\begin{array}{l}85.6 \\
87.3\end{array}$ & $\begin{array}{l}78.5 \\
80.6\end{array}$ & $\begin{array}{l}77.5 \\
80.0\end{array}$ & $\begin{array}{l}74.5 \\
76.2\end{array}$ & $\begin{array}{l}72.3 \\
70.4\end{array}$ & $\begin{array}{l}60.2 \\
56.4\end{array}$ & $\begin{array}{l}75.4^{a} \\
76.3^{b}\end{array}$ \\
\hline $\begin{array}{l}\text { Pore size } \\
10 \mu \mathrm{m} \\
42.5 \mu \mathrm{m}\end{array}$ & $\begin{array}{l}85.4 \\
87.6\end{array}$ & $\begin{array}{l}77.1 \\
82.0\end{array}$ & $\begin{array}{l}77.0 \\
80.5\end{array}$ & $\begin{array}{l}73.3 \\
77.4\end{array}$ & $\begin{array}{l}68.9 \\
73.7\end{array}$ & $\begin{array}{l}55.9 \\
60.8\end{array}$ & $\begin{array}{l}73.7^{a} \\
77.9^{b}\end{array}$ \\
\hline Mean & $86.5 a$ & $79.5^{b}$ & $78.8^{c}$ & $75.3^{d}$ & $71.3^{\circ}$ & $58.3^{\prime}$ & 75.8 \\
\hline
\end{tabular}

Means with different letters differ $(P<0.05)$. 